\title{
Brainstem auditory-evoked potential in Boxer $\operatorname{dogs}{ }^{1}$
}

\author{
Mariana Isa Poci Palumbo², Luiz Antonio de Lima Resende 3 , José Carlos de \\ Figueiredo Pantoja ${ }^{4}$, Ian G. Mayhew ${ }^{5}$ and Alexandre Secorun Borges ${ }^{6 *}$
}

\begin{abstract}
Palumbo M.I.P., Resende L.A.L., Pantoja J.C.F., Mayhew I.G. \& Borges A.S. 2014. Brainstem auditory-evoked potential in Boxer dogs. Pesquisa Veterinária Brasileira 34(10):1007-1010. Departamento de Clínica Veterinária, Faculdade de Medicina Veterinária e Zootecnia, Universidade Estadual Paulista, Distrito de Rubião Junior s/n, Botucatu, SP 18618970, Brazil. E-mail: asborges@fmvz.unesp.br

Brainstem auditory-evoked potential (BAEP) has been widely used for different purposes in veterinary practice and is commonly used to identify inherited deafness and presbycusis. In this study, 43 Boxer dogs were evaluated using the BAEP. Deafness was diagnosed in 3 dogs ( 2 bilateral and 1 unilateral) allowing the remaining 40 Boxers to be included for normative data analysis including an evaluation on the influence of age on the BAEP. The animals were divided into 2 groups of 20 Boxers each based on age. The mean age was 4.54 years (range, 1-8) in group I, and 9.83 years (range, $8.5-12$ ) in group II. The mean latency for I, III, and V waves were $1.14( \pm 0.07), 2.64( \pm 0.11)$, and $3.48( \pm 0.10) \mathrm{ms}$ in group I, and $1.20( \pm 0.12), 2.73( \pm 0.15)$, and $3.58( \pm 0.22) \mathrm{ms}$ in group II, respectively. The mean inter-peak latencies for the I-III, III-V and I-V intervals were $1.50( \pm 0.15), 0.84$ $( \pm 0.15)$, and $2.34( \pm 0.11) \mathrm{ms}$ in group I, and $1.53( \pm 0.16), 0.85( \pm 0.15)$, and $2.38( \pm 0.19)$ $\mathrm{ms}$ in group II, respectively. Latencies of waves I and III were significant different between group I and II. For the I-III, III-V and I-V intervals, no significant differences were observed between the 2 groups. As far as we know, this is the first normative study of BAEP obtained from Boxer dogs.
\end{abstract}

INDEX TERMS: Auditory evoked potential, latency, deafness, Boxer, dogs.

RESUMO.- [Potencial evocado auditivo de tronco encefálico em cães da raça Boxer.] 0 potencial evocado auditivo de tronco encefálico (PEATE) tem sido amplamente utilizado com diferentes finalidades na prática veterinária e é comumente usado para identificar a surdez hereditária e a presbiacusia. No presente estudo, 43 cães da raça

\footnotetext{
${ }^{1}$ Received on February 17, 2014.

Accepted for publication on July 27, 2014

${ }^{2}$ Departamento de Clínica Veterinária, Faculdade de Medicina Veterinária e Zootecnia (FMVZ), Universidade Estadual Paulista "Júlio de Mesquita Filho" (Unesp), Distrito de Rubião Junior s/n, Botucatu, SP 18618-970, Brazil. E-mail: palumboma11@yahoo.com.br

${ }^{3}$ Departamento de Neurologia, Psicologia e Psiquiatria, Faculdade de Medicina de Botucatu (FMB), Unesp, Distrito de Rubião Junior s/n, Botucatu, SP. E-mail: luan_resende@uol.com.br

${ }^{4}$ Departamento de Higiene Veterinária e Saúde Pública, FMVZ-Unesp, Botucatu, SP. E-mail: pantoja@fmvz.unesp.br

${ }^{5}$ Institute of Veterinary, Animal and Biomedical Sciences, College of Sciences, Massey University, Private Bag 11-222, Palmerston North, New Zealand. E-mail: i.g.mayhew@massey.ac.nz

${ }^{6}$ Departamento de Clínica Veterinária, FMVZ-Unesp, Botucatu, SP. *Corresponding author: asborges@fmvz.unesp.br
}

Boxer foram pelo teste PEATE. Foi diagnosticada surdez em 3 cães ( 2 bilaterais e 1 unilateral), e 40 Boxers foram usados no estudo normativo incluindo avaliação da influência da idade no PEATE. Os animais foram divididos de acordo com a idade em 2 grupos de 20 Boxers cada. A idade media foi 4,54 anos (variação de 1-8) no grupo I e 9,83 anos (variação de 8,5-12) no grupo II. A latência media das ondas I, III e V foram: $1,14( \pm 0,07) ; 2,64( \pm 0,11)$ e 3,48 $( \pm 0,10)$ ms no grupo I; e $1,20( \pm 0,12) ; 2,73( \pm 0,15)$ e 3,58 $( \pm 0,22)$ ms no grupo II, respectivamente. A latência media para os intervalos I-III, III-V e I-V foram $1,50( \pm 0,15) ; 0,84$ $( \pm 0,15)$ e $2,34( \pm 0,11)$ ms no grupo I; e $1,53( \pm 0,16) ; 0,85$ $( \pm 0,15)$ e $2,38( \pm 0,19)$ ms no grupo II, respectivamente. As latências das ondas I e III foram estatisticamente diferentes entre os grupos I e II. Não foram observadas diferenças estatísticas entre os dois grupos para os intervalos I-III, III-V e I-V. De acordo com a revisão realizada, este é o primeiro estudo normativo de BAEP realizado em cães da raça Boxer.

TERMOS DE INDEXAÇÃO: Potencial evocado auditivo, latência, surdez, Boxer, caninos. 


\section{INTRODUTION}

Brainstem auditory-evoked potentials (BAEP) can be a valuable neurologic diagnostic tool for veterinarians to evaluate hearing and to detect inner ear, VIII ${ }^{\text {th }}$ cranial nerve, or brainstem lesions (Marshall, 1985). These potentials are manifestations of the functional state of structures in the cochlea, the auditory nerve, and the central nervous system and can be detected using a non-invasive procedure. Therefore, BAEP has become widely used in human and veterinary medicine (Holliday \& Te Selle 1985).

Congenital hereditary hearing loss is a widespread problem occurring in approximately 80 breeds of dog (Strain 2004), and it is more commonly observed in dogs with white pigmentation (Muhle et al. 2002). In most dog breeds, inherited congenital sensorineural deafness results from perinatal degeneration of the stria vascularis, which appears to result from the local absence of functional melanocytes (Strain 1996). Behavioural responses to subjective hearing tests are difficult to interpret in pups or untrained adult dogs (Marshall 1986). For this reason, BAEP is a reasonable test for hearing evaluations in young pups (Marshall 1986).

The use of BAEP testing to diagnose congenital sensorineural deafness has been extensively studied in dogs over the past 30 years (Bodenhamer et al. 1985, Haagen et al. 1989, Kawasaki \& Inada 1994, Juraschko et al. 2003, Platt et al. 2006, Wilson et al. 2011). The breeds with the highest prevalence of deafness include the Australian Cattle Dog, Australian Shepherd, Bull Terrier, Catahoula, Dalmatian, English Cocker Spaniel, English Setter and West Highland White Terrier (Strain 1996). The occurrence of deafness has been reported for many breeds, but as far as we know, no published study is available for Boxer dogs in Brazil.

Age related hearing loss [presbycusis] is purported to be the most common form of acquired clinical deafness in dogs (Haar et al. 2008) and some authors have described alterations in BAEP waveforms to advancing age in dogs (Knowles et al. 1988, Shimada et al. 1998, Haar et al. 2008). High noise, heredity and systemic degenerative changes also appear to contribute to the development of age-related hearing loss (Haar et al. 2008). Thus, age should always be considered when results of BAEP tests are interpreted. The aim of this study is to present normative data for BAEP testing in Boxer dogs, including the influence of age, and to report on the occurrence of deafness in this breed.

\section{MATERIALS AND METHODS}

Approval was given for this experiment by the Ethics Committee on Animal Research for our Institution (process 117/2009). Forty-three adult Boxer dogs were evaluated using BAEP testing (41 dogs had no previous deafness complaint and 2 dogs were referred to confirm deafness). The dogs came from owners who provided consent prior to testing. Each dog was evaluated clinically, including neurological and otoscopic examinations. Animals with neurological disorders, the presence of excess cerumen in the external auditory canal, or other abnormalities were excluded. The animals were divided into two groups: Group I included dogs aged 1 to 8 years old, and Group II included dogs $>8$ years old.
BAEP tests were performed at the Veterinary Clinical Science Laboratory of Electrodiagnostics of UNESP, Botucatu. During examinations, the dogs were no sedated and were kept in a standing position or in sternal recumbency using only calming physical restraint. The body temperature of the animals was evaluated and ranged from $38.2^{\circ} \mathrm{C}$ to $39.2^{\circ} \mathrm{C}$.

The active (inverting) monopolar needle electrode (G1) was inserted subcutaneously at a point just rostral to the base of each ear and a similar reference electrode (G2) was inserted at the vertex (Kay et al. 1984). The ground electrode was placed subcutaneously in the cervical dorsal neck (Holliday \& Selle 1985, Marshall 1986, Eger \& Lindsay 1997). The band-pass filter was set at $200 \mathrm{~Hz}$ to $3.000 \mathrm{~Hz}$, the sensitivity was set to $2.5 \mu \mathrm{V} / \mathrm{cm}$ and the analysis time to $1 \mathrm{~ms} / \mathrm{cm}$. The headphone was positioned manually over the external auditory meatus of the dog. Rarefaction clicks with $0.2 \mathrm{~ms}$ duration, $85 \mathrm{~dB}$ NHL intensity, and $13 \mathrm{~Hz}$ frequency were employed. Contralateral white-noise masking of $40 \mathrm{~dB}$ was used (Chiappa 1997). A minimal of 2 series with 500 stimuli each were averaged.

All examinations were performed using a Synergy Viasys Healthcare $^{\circledR}$ equipment. In each test, the absolute latencies of waves I, III and V, and the I-III, III-V and I-V intervals for each side were measured. Initially, the distribution of variables was analyzed and no abnormalities were found. Descriptive statistics were produced to characterize the average latency of waves (ms) in the groups studied. A linear mixed model (PROC MIXED, SAS Institute, 2009) was used to compare the average latency of each wave studied between groups and sides within the same animal. A compound symmetry covariance structure was used to model the correlation between measurements within the same animal (each dog was considered a cluster). The level of statistical significance was set at 0.05 .

\section{RESULTS}

Two dogs were suspected to be deaf because they did not respond to auditory cues and were confirmed with BAEP test. Unilateral absence of a response, suggesting unilateral sensorineural deafness, was observed in $1 \mathrm{dog}$. The study included 29 brown- and 14 white-coated boxers. No deaf dog had a brown coat colour. The 2 bilateral deaf dogs had white coat pigmentation, and one of these dogs had one blue iris and one brown iris (Fig.1A and B). The dog with unilateral deafness was white with a brown periocular patch (Fig.1C, Table1) and brown iris.

The normative study included 40 dogs were divided into two groups, with 20 dogs in each group. The mean age of the dogs was 4.54 years (range, 1-8) in group I and 9.83

Table 1. Mean and standard deviation of waves (I, III and V) and intervals (I-III, III-V and I-V) latencies in milliseconds (ms) of each group of 20 Boxer dogs

\begin{tabular}{lccccc}
\hline \multirow{2}{*}{ Latency } & \multicolumn{2}{c}{ Group I } & & \multicolumn{2}{c}{ Group II } \\
\cline { 2 - 3 } \cline { 5 - 6 } & Mean (ms) & SD & & Mean (ms) & SD \\
\hline I & $1.14^{\mathrm{a}}$ & 0.07 & & $1.20^{\mathrm{b}}$ & 0.12 \\
III & $2.64^{\mathrm{a}}$ & 0.11 & & $2.73^{\mathrm{b}}$ & 0.15 \\
V & $3.48^{\mathrm{a}}$ & 0.10 & & $3.58^{\mathrm{a}}$ & 0.22 \\
I-III & $1.50^{\mathrm{a}}$ & 0.15 & & $1.53^{\mathrm{a}}$ & 0.16 \\
III-V & $0.84^{\mathrm{a}}$ & 0.15 & & $0.85^{\mathrm{a}}$ & 0.15 \\
I-V & $2.34^{\mathrm{a}}$ & 0.11 & & $2.38^{\mathrm{a}}$ & 0.19
\end{tabular}

Differences letters in the same line means significant difference between groups $(\mathrm{p}<0,05)$. Results for both ears were combined, giving a total of 40 ears tested in each group. 


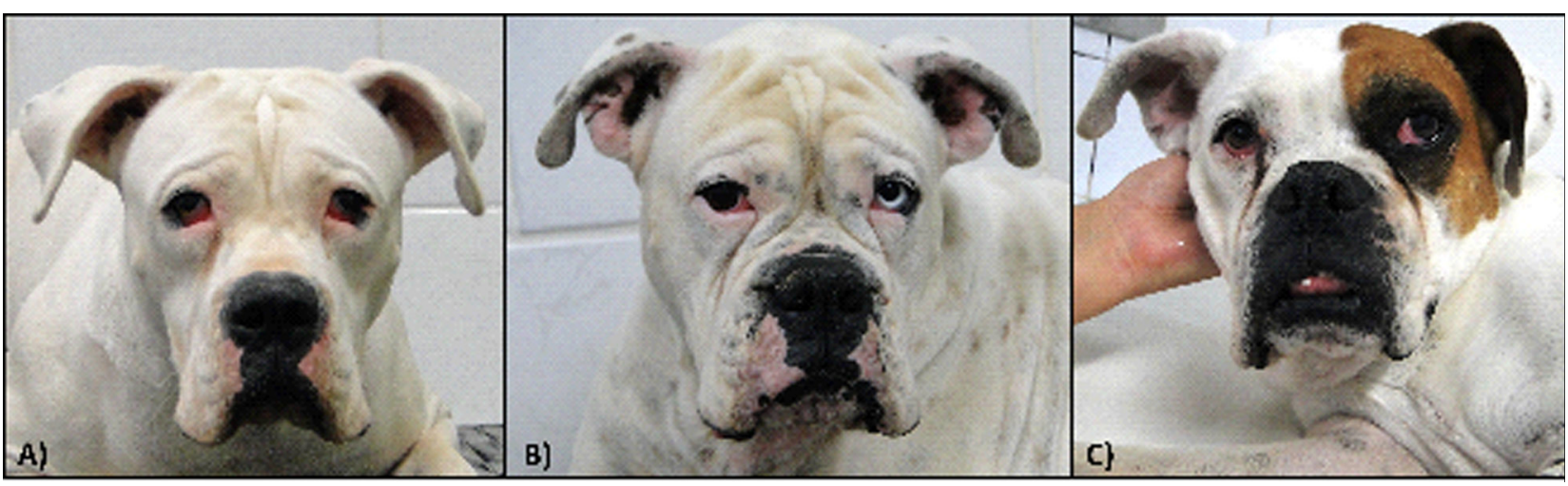

Fig.1. (A) Bilateral deaf dog with white coat pigmentation and brown iris color. (B) Bilateral deaf dog with white coat pigmentation, blue iris color in one side and brown in the other side. (C) Unilateral deaf dog with white coat pigmentation and a brown periocular patch.

years (range, 8.5-12) in group II. Left-versus-right data differences were not significant, so all results for both ears were combined, giving 80 results (40 in each group). The mean and standard deviation of the absolute wave latencies and intervals for the 2 groups are shown in Table 2. The I and III wave latencies were increased in group II compared to group I and no significant differences for the inter-peak intervals were observed.

\section{DISCUSSION}

This study appears to be the first to describe the occurrence of deafness in Boxer dogs in Brazil. We found unilateral deafness in 1 and bilateral deafness in 2 Boxers. Other studies that have evaluated the incidence of deafness showed a higher incidence of unilateral deafness compared to bilateral deafness in different breeds, such as Border Collies (2.3\% unilateral and $0.5 \%$ bilateral) (Platt et al. 2006), Bull Terriers (9.9\% unilateral and 1.1\% bilateral) (Strain 2004), Australian cattle dogs $(12.2 \%$ unilateral and $2.4 \%$ bilateral) (Strain 2004), English Setters (12.7\% unilateral and 2.4 bilateral) (Strain 1996) and English Cocker Spaniels (7\% unilateral and 1.8\% bilateral) (Strain 1996). The fact that this report found more bilateral deafness than unilateral, when other published reports, studying other bree$\mathrm{ds}$, found a higher prevalence of unilateral than bilateral, is certainly the result of the small sample size.

Deafness in dogs is frequently associated with altered expression of pigment genes, such as piebald and merle (Strain et al. 2009), and several prior studies have identified statistically significant associations between deafness and a blue iris colour and white coat pigmentation (Strain 2004, Platt et al. 2006, Famula et al. 2007). Since not all dogs with piebald are deaf or have blue eyes, it can be argued that this variable outcome is the consequence of incomplete penetrance of a causative gene, or that one or more additional genes regulate the expression of the pigment gene (Strain 2011a). The method of genetic transmission of deafness in dogs is usually not known, and should be explained by a multi-gene cause, the presence of two different autosomal recessive deafness genes, or a syndrome with incomplete penetrance (Strain 2011b). In the present study the occurrence of deafness was higher in Boxers with white coat pigmentation and 1 deaf dog had a blue iris; however, no genetic study was performed.

The values of the wave latencies and intervals observed in this study are in agreement with those obtained in other studies using different dog breeds (Marshall 1985, Myers et al. 1985, Knowles et al. 1988, Haagen et al. 1989, HarcourtBrown et al. 2011). Many studies have reported that head size influences the amplitude and latency of waves (Allison et al. 1983, Trune et al. 1988, Pook \& Steiss 1990, Meij et al. 1992). Animals greater than 1-year-old were selected to reduce the influence of head size in the normative study. Increases in the latency of all waves of dogs with rectal temperatures below $36^{\circ} \mathrm{C}$ were reported (Bodenhamer et al. 1985). To minimise the interference of temperature, in this study temperature was controlled between 38.2 and $39.2^{\circ} \mathrm{C}$.

Age-related hearing loss in medium-sized breeds starts at approximately 8-10 years of age, and there have been no reports of the age of onset of presbiacusis in other sized breeds - including boxers. (Ter Haar et al. 2008). Some authors related alterations in BAEP waveforms to advanced age, including increased latency and decreased amplitude (Knowles et al. 1988), higher thresholds (Haar et al. 2008), and the absence of waves (Shimada et al. 1998). In this stu$d y$, we used only one stimulus level and compared the mean latencies of waves in two groups of dogs with different ages. The average latency of waves I and III were greater in dogs over 8 years of age. However, advanced age did not affect the latency of wave $V$ and the inter-peak latencies.

\section{CONCLUSION}

This study presents normative BAEP data for Boxers and reports deafness in this dog breed. The values of wave latencies obtained in this study can be used as the normal reference for comparisons in Boxer dogs with different diseases and also for studying dogs with different ages.

Acknowledgements.- This study was supported by grants from Fundação de Amparo à Pesquisa do Estado de São Paulo (FAPESP, Process 2009/12290-8 and 2010/00518-1).

\section{REFERENCES}

Allison T., Wood C.C. \& Goff W.R. 1983. Brain stem auditory, pattern-reversal visual, and short- latency somatosensory evoked potentials: laten- 
cies in relation to age, sex, brain and body size. Electroencephalogr. Clin. Neurophysiol. 55:619-636.

Bodenhamer R.D., Hunter J.F. \& Luttgen P.J. 1985. Brain stem auditory evoked response in the dog, Am. J. Vet. Res. 46:1787-1792.

Eger C.E. \& Lindsay P. 1997. Effects of otitis on hearing in dogs characterized by brainstem auditory evoked response testing. J. Small Anim. Pract. 38:380-386.

Famula T.R., Cargill E.J. \& Strain G.M. 2007. Heritability and complex segregation analysis of deafness in Jack Russell Terriers. BMC Vet. Res. 31:1-11.

Haagen V.A.J., Siemelink R.J.G. \& Smoorenburg G.F. 1989. Auditory brainstem response in the normal beagle. Vet. Quart. 11:129-137.

Harcourt-Brown T.R., Parker J.E., Granger N. \& Jeffery N.D. 2011. Effect of middle ear effusion on the brain- stem auditory evoked response of Cavalier King Charles Spaniels. Vet. J. 188:341-345.

Holliday T.A. \& Te Selle M.E. 1985. Brain stem auditory-evoked potentials of dogs:wave forms and effects of recording electrode positions. Am. J. Vet. Res. 46:845-851.

Juraschko K., Meyer-Lindenberg A., Nolte I. \& Distl O. 2003. Analysis of systematic effects on congenital sensorineural deafness in German Dalmatian dogs. Vet. J. 166:164-169.

Kawasaki Y. \& Inada S. 1994. Peaks of brainstem auditory evoked potentials in dogs. Vet. Res. Commun. 18:383-396.

Kay R., Palmer A.C. \& Taylor P.M. 1984. Hearing in the dog as assessed by auditory brainstem evoked potentials. Vet. Rec. 114:81-84.

Knowles K.E., Cash W.C. \& Blauch B.S. 1988. Auditory-evoked responses of dogs with different hearing abilities. Can. J. Vet. Res. 52:394-397.

Marshall A.E. 1985. Brain stem auditory-evoked response of the nonanesthetized dog. Am. J. Vet. Res. 46:966-973.

Marshall A.E. 1986. Use of brain stem auditory-evoked response to evaluate deafness in a Dalmatian dogs. J. Am. Vet. Med. Assoc. 188:718722.

Meij B.P., Venker-Van Haagen A.J. \& Van den Brom W.E. 1992. Relationship between latency of brainstem auditory-evoked potentials and head size in dogs. Vet. Quart. 14:121-126.

Muhle A.C., Jagg A., Stricke C., Steff F., Dol G., Busat A., Kornber M., Mariscol M., Sren P. \& Gaillar C. 2002. Further contributions to the genetic aspect of congenital sensorineural deafness in Dalmatians. Vet. J. 163: 311-318.

Myers L.J., Redding R.W. \& Wilson S. 1985. Reference values of the brainstem auditory evoked response of methoxyflurane anesthetized and unanesthetizes dogs. Vet. Res. Commun. 9:289-294.

Platt S., Freeman J., Stefani A.D., Wieczorek L. \& Henley W. 2006. Prevalence of unilateral and bilateral deafness in Border Collies and association with phenotype. J. Vet. Intern. Med. 20:1355-1362.

Pook H.A. \& Steiss J.E. 1990. Correlation of brain stem auditory-evoked responses with cranium size and body weight of dogs. Am. J. Vet. Res. 51:1779-1783.

Shimada A., Ebisu M., Morita T., Takeuchi T. \& Umemura T. 1998. Age-related changes in the cochlear nuclei of dogs. J. Vet. Med. Sci. 60:41-48.

Strain G.M. 1996. Aetiology, prevalence and diagnosis of deafness in dogs and cats. Brit. Vet. J. 152:17-36.

Strain G.M. 2004. Deafness prevalence and pigmentation and gender associations in dog breeds at risk. Vet. J. 167:23-32.

Strain G.M., Clark L.A., Wahl J.M., Turner A.E. \& Murphy K.E. 2009. Prevalence of deafness in dogs heterozygous or homozygous for the Merle allele. J. Vet. Intern. Med. 23:282-286.

Strain G.M. 2011a. White noise: pigment-associated deafness. Vet. J. 188:247-249.

Strain G.M. 2011b. Hereditary deafness, p.53-60. In: Strain G.M. (Ed.), Deafness in Dogs and Cats. CABI, Oxfordshire. 158p.

Ter Haar G., Venker-Van Haagen A.J., Van den Brom W.E., Van Sluijs F.J. \& Smoorenburg G.F. 2008. Effects of aging on brainstem responses to toneburst auditory stimuli: a cross-sectional and longitudinal study in dogs. J. Vet. Intern. Medicin. 22:937-945.

Trune D.R., Mitchell C. \& Phillips D.S. 1988. The relative importance of head size, gender and age on the auditory brainstem response. Hearing Research 32:165-174.

Wilson W.J., Mills P.C., Bradley A.P., Petoe M.A., Smith A.W.B. \& Dzulkarnain A.A. 2011. Fast assessment of canine hearing using high click-rate BAER. Vet. J. 187:136-138.

Chiappa K.H. 1997. Brain stem auditory evoked potentials: methodology, p.157-197. In: Chiappa K.H. (Ed.), Evoked Potentials in Clinical Medicine. Lippincott-Raven, Philadelphia. 580p. 